\title{
Measuring the Identity, Local Democracy and Transformative Politics: A Critical Case of the Jakarta Gubernatorial Election 2017
}

\author{
Theresia Octastefani \\ Universitas Gadjah Mada Yogyakarta, Indonesia \\ theresiaoctastefani@ugm.ac.id
}

\begin{abstract}
The Jakarta Gubernatorial Election 2017 is an important momentum for improving and evaluating the quality of democracy at the local level. Various issues of religion, ethnicity, as well as differences in political support, colored both in the first and second round. Anies-Sandi's victory in this local election is interesting to study further by using the political representation approach by Olle Törnquist. The results of this study showed that voters have been polarized through strengthening religious and ethnic sentiments so it can be ignored the factor of achievement, capacity, and track record of candidates. Extensive efforts to spread identity politics were carried out through various movements and actors. The quality of political participation among DKI Jakarta residents can also be seen from the extent of voter autonomy and literacy in determining positions. Based on those results, a critical discussion of the Jakarta Gubernatorial Election 2017 will be a reflection of useful learning to observe the political climate, which transform relation to connect or disconnect relations between constituent and their representative.
\end{abstract}

Keywords: identity; local democracy; transformative politics; Jakarta Gubernatorial Election.

\section{Abstrak}

Pemilihan Gubernur DKI Jakarta 2017 menjadi momentum penting untuk meningkatkan dan mengevaluasi kualitas demokrasi di tingkat lokal. Berbagai isu terkait agama, etnis, serta perbedaan dukungan politik turut mewarnai baik di putaran pertama maupun kedua. Kemenangan Anies-Sandi dalam pemilukada ini menarik untuk diteliti lebih lanjut dengan menggunakan pendekatan representasi politik yang dikemukakan oleh Olle Törnquist. Hasil penelitian ini menunjukkan bahwa voters telah terpolarisasi melalui menguatnya sentimen agama dan etnisitas sehingga seolah mengabaikan faktor prestasi, kapasitas, dan rekam jejak kandidat. Upaya luas untuk menyebarkan politik identitas dilakukan melalui berbagai gerakan dan aktor. Kualitas partisipasi politik di antara penduduk DKI Jakarta juga dapat dilihat dari tingkat otonomi dan literasi pemilih dalam menentukan posisi. Berdasarkan temuan tersebut, tinjauan kritis dari Pemilihan Gubernur DKI Jakarta 2017 menjadi refleksi pembelajaran berharga untuk meninjau iklim politik dimana dapat mentransformasi relasi untuk memperkuat atau justru memutuskan hubungan antara konstituen dengan wakil politiknya.

Kata kunci: identitas; demokrasi lokal; politik transformative; PilGub DKI Jakarta. 
Al Izzah: Jurnal Hasil-Hasil Penelitian-ISSN: 1978-9726 (p); 2541-0717 (e)

Volume 14, Nomor 2 (November, 2019))

\section{A. Introduction}

Based on the fourth amendment of the Indonesian Constitution (UUD) 1945, Indonesia has three types of electoral events: legislative elections, presidential elections, and local elections. Election complexity varies greatly depending on the electoral system, the management of the election, the candidates, and the level of voter literacy regarding the election. Elections in Indonesia are political events that are repeated every five years. Since 2005, direct local elections (one man one vote) have been held at the provincial, regency, and city levels not only for legislature membership, but also for filling gubernatorial, regent, and mayoral positions. Local communities can use their political rights to participate and directly vote on their area's local leadership. In this way, the spirit to bring closer relations between leaders and local society can be realized, and democracy can be strengthened at the local level.

The implementation of direct local elections is also a political step undertaken in the reform era to concretize Law No. 32 of 2004 about Local Government. Some quite fundamental changes have been made to local elections in Indonesia, especially to their mechanisms and how local leaders are elected directly. ${ }^{1}$ The implementation of direct local elections is considered a breakthrough in the organization of local democracy within the framework of political liberalization. This change is expected to minimize the gap between the people's desires and the candidates running. As such, during the transition period, direct local elections are an important part of decentralization and regional autonomy. The election of leaders at the local level is expected to create clean local governance, provide citizens equal rights in politics, and open space for the Indonesian people to become actively involved in politics as an effort to strengthen national democracy. The local leaders can be produced through direct local elections and the greater commitment of local leaders will realize the goals of local autonomy.

The implementation of local election was strengthened in the various regions in Indonesia, especially a decade later, in 2015, when Law No. 8 of 2015 on the Amendment of Law No. 1 of 2015 about the Stipulation of Government Regulation in Lieu of Law No. 1 of 2014 about the Election of Governors, Regents, and Mayors. Ratification of this law followed the passing of Law No. 23 of 2014 about Local Government as a replacement for Law No. 32 of 2004. Ratification of this rule had political consequences on the simultaneous conduction of local elections throughout all regions of Indonesia. Article 201, paragraphs $1-7$ of Law No. 8 of 2015, states that simultaneous local election (pemillukada serentak) are to be held in seven waves (2015, 2017, 2018, 2020, 2022, 2023, and 2027) and held on the same day, date, month, and year in some areas of Indonesia. Each wave of elections is intended to adjust the end of the regional leaders' term.

${ }^{1}$ See Budi F. Hardiman. “Demokrasi Deliberatif: Model untuk Indonesia Pasca-Soeharto?”, Majalah Basis No. 11-12 (2004). 
Simultaneous local elections have become a new chapter in local democracy. Simultaneous elections were born of the idea and spirit of improving the quality of local elections, which had been perceived as capitalistic and transactional. ${ }^{2}$ Simultaneous elections were not intended merely as a matter of dates, months, and years coinciding with other regions to simplify election timing, but rather to emphasize the quality and maturity of local democracy and elections. This is consistent with the statement by Brian C. Smith and Robert Dahl who mention that local accountability, political equity, and responsiveness are at stake in every region as it builds democracy at the local level. ${ }^{3}$ As such, concurrent local elections are expected to be the first step to building a more stable and effective local government order, one that is capable of improving social, political and economic conditions. Such elections are also intended to organize the national election cycle.

From various simultaneous local elections that have been carried out in 2017, in this paper, the DKI Jakarta elections 2017 will be the focus of this research and it is important to study it more deeply. The author aware that a similar study has been investigated quite intensively by the previous researcher, for example: First, the rise of Islamic identity politics takes place through efforts to develop self-image and uphold selfesteem as humiliated Muslims so they must choose those who have the same religion. This is to build psychology as a wounded majority as well as a space to build the majority power limit to those who are seen as minorities to maintain the demarcation of power in the name of religion. ${ }^{4}$ Second, in the election of the DKI Jakarta governor in 2017, with a certain identity, prospective candidates could carry out bargaining positions. This shows that ethnic and religious factors are significant enough to get support and influence people's choices. ${ }^{5}$

When compared with other similar studies, the novelty offered in this study are: First, this study will examine the phenomena based on political representation model by Olle Törnquist. Second, this study offers a detailed chronological analysis by comparing the initiator and demands of each Islamic Defender Action (Aksi Bela Islam) to dissect the political motives behind the action. Third, this study will critically analyze how political transformation in Indonesia's local democracy in the future is related to the strengthening of the issue of identity politics.

\footnotetext{
${ }^{2}$ See Edward Aspinall and Mada Sukmajati (eds.). Politik Uang di Indonesia: Patronase dan Klientelisme di Pemilu Legislatif 2014. (Yogyakarta: PolGov UGM, 2015).

${ }^{3}$ Idil Akbar. "Pilkada Serentak dan Geliat Dinamika Politik dan Pemerintahan Lokal Indonesia". CosmoGov: Jurnal Ilmu Pemerintahan Vol. 2 No. 1 (2016). 95-110.

4 Endang Sari. "Kebangkitan Politik Identitas Islam Pada Arena Pemilihan Gubernur Jakarta". Kritis: Jurnal Ilmu Sosial dan Ilmu Politik Vol. 2 No. 2, (2016).

${ }^{5}$ Andy Prima Sahalatua et al. "Politik Identitas dalam Pemilihan Kepala Daerah (Studi Kasus pada Pemilihan Gubernur DKI Jakarta Periode 2017-2022)". Prosiding Seminar Nasional Prodi Ilmu Pemerintahan, (2018).
} 


\section{B. Religion, Ethnicity, and the Political Dynamics in Jakarta 2017}

Before 2017, the Indonesian Elections Commission (KPU) had succeeded in conducting the first wave of simultaneous local elections on December 9, 2015, followed by 9 provinces, 224 regencies, and 36 cities; and the second wave of elections, held on February 15, 2017 and followed by 7 provinces, 76 regencies, and 18 cities. The complexity of the issue also colored the implementation of the Jakarta Gubernatorial Election in 2017. This election entered the spotlight of various groups, both domestically and abroad, because Jakarta is the miniature of Indonesia. This public spotlight cannot be separated from the printed, electronic, and social media's incessant competition in reporting data, facts, and hoaxes regarding the three pairs of gubernatorial and vicegubernatorial candidates: First, Agus Harimurti Yudhoyono and Sylviana Murni (AgusSylvi); second, Basuki Tjahaja Purnama and Djarot Saiful Hidayat (Ahok-Djarot); third, Anies Rasyid Baswedan and Sandiaga Salahuddin Uno (Anies-Sandi). News about the Jakarta election was more prominent than election news from regencies and cities throughout Indonesia. ${ }^{6}$ Indeed, coverage of the Jakarta election gave the impression that it was the only election being contested, as it managed to seize the attention of various layers of society. Persons throughout Indonesia followed the election process, from candidate nominations until the end of the second round.

The hopes and support of Jakarta residents were polarized for or against each gubernatorial and vice gubernatorial candidate. News in various media bring out the picture that this polarization emerged because of various factors, including: the existence of emotional connections (religious, ethnicity, racial, etc.); political relations (equality of policymakers); common vision and mission; etc. Over time, this polarization became stronger and increased the political temperature in Jakarta. Various rumors were manipulated to attack candidates. Of the many rumors reported, the one of religious defamation proved effective in spreading hatred and strengthening identity sentiments and sensitivity within the community during the first and second round of elections. This condition is strengthened and reached a tipping point on October 6, 2016 after a short video was edited and uploaded by a netizen named Buni Yani on his Facebook. ${ }^{7}$ This video, titled "Penistaan Terhadap Agama?", was circulated through various social media. The edited video presented Ahok making a statement, quoting verse 51 of the Surah Al Ma'idah that has been understood by some as besmirching the Qur'an and offending Muslims. In this statement, Ahok urges listeners 'not to be fooled' by those who use Al Ma'idah verse 51 of the Quran to claim that it is a sin for Muslims to vote for a non-

${ }^{6}$ Switzy Sabandar. Riset UGM: Ahok dan Pilkada DKI Isu Paling Populer Sepanjang 2016. Retrieved from https://www.liputan6.com/news/read/2836414/riset-ugm-ahok-dan-pilkada-dki-isu-palingpopuler-sepanjang-2016.

${ }^{7}$ CNN Indonesia. Kronologi Kasus Buni Yani, Penyebar Video Ahok Soal Al Maidah. Retrieved from https://www.cnnindonesia.com/nasional/20161124075029-12-174911/kronologi-kasus-buni-yanipenyebar-video-ahok-soal-al-maidah. 
Al Izzah: Jurnal Hasil-Hasil Penelitian-ISSN: 1978-9726 (p); 2541-0717 (e)

Volume 14, Nomor 2 (November, 2019))

Muslim leader. This video eventually became the main trigger for the development of identity politics in Jakarta. It was employed by a number of elite political parties and candidates as a strategy to beat Ahok and Djarot in the first round. This strategy considered the demographics of Jakarta, where almost $85 \%$ of the population is Muslim. This video became viral and led to a variety of actions. At least seven actions, labeled Islamic martial and peace actions, were held:

Table 1; Detail Chronology of Islamic Defense Actions during the Jakarta Gubernatorial Election 2017

\begin{tabular}{|c|c|c|c|}
\hline $\begin{array}{c}\text { Name of } \\
\text { Action }\end{array}$ & Date and Place & Initiator & Action \\
\hline $\begin{array}{l}\text { Islamic } \\
\text { Defense } \\
\text { Action I }\end{array}$ & $\begin{array}{l}\text { October } \\
2016, \quad \text { Istiqlal } \\
\text { Mosque. Ended } \\
\text { in front of } \\
\text { Jakarta City Hall }\end{array}$ & $\begin{array}{l}\text { Thousands } \\
\text { Islamic } \\
\text { organizations, led } \\
\text { by the Islamic } \\
\text { Defenders Front } \\
\text { (Front Pembela } \\
\text { Islam, FPI) }\end{array}$ & $\begin{array}{l}\text { This was the first action held } \\
\text { by thousands of Islamic } \\
\text { community organizations led } \\
\text { by the FPI. The action started } \\
\text { with Friday prayers at the } \\
\text { Istiqlal Mosque, then } \\
\text { continued in front of the } \\
\text { Office of Criminal } \\
\text { Investigation at the Ministry } \\
\text { of Maritime Affairs and } \\
\text { Fisheries. It ended in front of } \\
\text { the Jakarta City Hall. The } \\
\text { masses demanded that Ahok } \\
\text { be investigated by the police } \\
\text { and charged with blasphemy. } \\
\text { They threatened a larger } \\
\text { action if the case did not } \\
\text { resume in three weeks. }\end{array}$ \\
\hline $\begin{array}{l}\text { Islamic } \\
\text { Defense } \\
\text { Action II }\end{array}$ & $\begin{array}{l}\text { November } 4, \\
2016 \text {, Istiqlal } \\
\text { Mosque. Ended } \\
\text { in front of } \\
\text { Presidential } \\
\text { Palace on West } \\
\text { Merdeka Street }\end{array}$ & $\begin{array}{l}\text { Thousands of } \\
\text { Islamic } \\
\text { organizations, led } \\
\text { by National } \\
\text { Movement of Fatwa } \\
\text { Enforcers for the } \\
\text { Indonesian Ulema } \\
\text { Council (Gerakan } \\
\text { Nasional Pengawal } \\
\text { Fatwa Majelis } \\
\text { Ulama Indonesia, } \\
\text { GNPF-MUI) }\end{array}$ & $\begin{array}{l}\text { Better known as Islamic } \\
\text { Defense Action Volume II or } \\
\text { the } 411 \text { Peace Action. This } \\
\text { action was conducted in } \\
\text { response to a view that the } \\
\text { police investigation of Ahok } \\
\text { was being conducted too } \\
\text { slowly. To demand an } \\
\text { immediate response, this } \\
\text { action attempted to draw } \\
\text { more participants and used } \\
\text { the front of the Presidential } \\
\text { Palace as its venue. In }\end{array}$ \\
\hline
\end{tabular}


Al Izzah: Jurnal Hasil-Hasil Penelitian-ISSN: 1978-9726 (p); 2541-0717 (e)

Volume 14, Nomor 2 (November, 2019))

\begin{tabular}{|c|c|c|c|}
\hline & & & $\begin{array}{l}\text { addition to Jakarta, similar } \\
\text { actions were also held in } \\
\text { several other cities. Eleven } \\
\text { days later, on November } 15 \text {, } \\
\text { 2016, Ahok was named a } \\
\text { suspect. }\end{array}$ \\
\hline $\begin{array}{l}\text { Islamic } \\
\text { Defense } \\
\text { Action III }\end{array}$ & $\begin{array}{l}\text { December 2, } \\
\text { 2016, held on } \\
\text { Sudirman Street } \\
\text { and Thamrin } \\
\text { Street, with the } \\
\text { imam at Hotel } \\
\text { Indonesia } \\
\text { Boulevard } \\
\text { (Bundaran HI) }\end{array}$ & GNPF-MUI, FPI & $\begin{array}{l}\text { Better known as the } 212 \\
\text { Peace Action. This action } \\
\text { involved peaceful Friday } \\
\text { prayers together with } \\
\text { President Joko Widodo. This } \\
\text { activity was conducted to } \\
\text { pray for the salvation of the } \\
\text { country. In addition, this } \\
\text { action was also done to } \\
\text { protest Ahok not having been } \\
\text { detained by the police despite } \\
\text { having been named a suspect. }\end{array}$ \\
\hline $\begin{array}{l}\text { Islamic } \\
\text { Defense } \\
\text { Action IV }\end{array}$ & $\begin{array}{l}\text { February 11, } \\
2017 \text {, held at } \\
\text { Istiqlal Mosque }\end{array}$ & $\begin{array}{l}\text { Islamic } \\
\text { Congregation } \\
\text { Forum (Forum } \\
\text { Umat Islam, FUI) } \\
\text { and GNPF-MUI }\end{array}$ & $\begin{array}{l}\text { Better known as Action } 112 \text {. } \\
\text { This action was a follow-up } \\
\text { action to Islamic Defense } \\
\text { Actions I-III. It was carried } \\
\text { out by holding a prayer } \\
\text { recital and sermons at Istiqlal } \\
\text { Mosque, Jakarta, after the } \\
\text { Chairman of FPI and the } \\
\text { leader of GNPF-MUI met } \\
\text { with the Coordinating } \\
\text { Minister for Politics, Law, } \\
\text { and Security Wiranto. This } \\
\text { action was another protest of } \\
\text { the Ahok case. }\end{array}$ \\
\hline $\begin{array}{l}\text { Islamic } \\
\text { Defense } \\
\text { Action V }\end{array}$ & $\begin{array}{l}\text { February 21, } \\
2017, \text { held at the } \\
\text { House of } \\
\text { Representatives } \\
\text { Senayan, Central } \\
\text { Jakarta }\end{array}$ & FUI & $\begin{array}{l}\text { Better known as Action } 212 . \\
\text { This action demanded that: } \\
\text { First, Parliament/Senate send } \\
\text { a letter to President Joko } \\
\text { Widodo regarding the } \\
\text { deactivation of Ahok. } \\
\text { Second, Ahok be declared } \\
\text { unfit to remain in office } \\
\text { owing to his status as a }\end{array}$ \\
\hline
\end{tabular}


Al Izzah: Jurnal Hasil-Hasil Penelitian-ISSN: 1978-9726 (p); 2541-0717 (e)

Volume 14, Nomor 2 (November, 2019))

\begin{tabular}{|c|c|c|}
\hline & & $\begin{array}{l}\text { defendant accused of } \\
\text { blasphemy. Third, Law } \\
\text { enforcers stop accusing } \\
\text { Islamic scholars and students } \\
\text { of crime. }\end{array}$ \\
\hline $\begin{array}{l}\text { Islamic } \\
\text { Defense } \\
\text { Action VI }\end{array}$ & $\begin{array}{l}\text { March } 31,2017 . \\
\text { First held at Islamic and various } \\
\text { Istiqlal Mosque, organizations } \\
\text { then moved to } \\
\text { the Presidential } \\
\text { Palace }\end{array}$ & $\begin{array}{l}\text { Better known as Action } 313 . \\
\text { This action demanded that } \\
\text { President Joko Widodo } \\
\text { dismiss Ahok from his } \\
\text { position as Governor of } \\
\text { Jakarta. At the time of this } \\
\text { action, President Joko } \\
\text { Widodo was meeting the } \\
\text { Chairman of the Indonesian } \\
\text { Ulama Council (MUI), KH } \\
\text { Ma'rif Amin. }\end{array}$ \\
\hline $\begin{array}{l}\text { Islamic } \\
\text { Defense } \\
\text { Action VII }\end{array}$ & $\begin{array}{l}\text { May 5, 2017. GNPF-MUI } \\
\text { First held at } \\
\text { Istiqlal Mosque, } \\
\text { then moved to } \\
\text { the Office of the } \\
\text { Supreme Court }\end{array}$ & $\begin{array}{l}\text { Better known as Action 55. It } \\
\text { was the closing act in the } \\
\text { series of Islamic defensive } \\
\text { actions. This action started } \\
\text { with Friday prayers at Istiqlal } \\
\text { Mosque, followed by a long } \\
\text { march to the Supreme Court } \\
\text { Office. This action was held } \\
\text { before the verdict in Ahok's } \\
\text { trial was read by the judges } \\
\text { on } 9 \text { May } 2017 \text {. In this action, } \\
\text { protestors demanded that the } \\
\text { Indonesian judicial } \\
\text { institution maintain legal } \\
\text { justice by punishing Ahok, } \\
\text { who had been charged for } \\
\text { blasphemy against Islam. }\end{array}$ \\
\hline
\end{tabular}

Source: Processed from various related data, 2018.

These various "Islamic defense actions" were intended to spread hatred and raise support for non-Muslim gubernatorial candidates being forbidden from running; this was targeted at Ahok, who held the status of double minority (Chinese and Christian). The seventh Islamic defense action in particular gave the impression that the election was being contested not between three gubernatorial potential candidates who had different visions and missions for realizing a better Jakarta over five years, but rather a battle between Muslim and non-Muslim leaders. This also proves the statement of Jeffrie 
Geovanie who argues that Islam is often used as the basis of political ideology and the basis of political struggle. ${ }^{8}$ Or if we borrow the M.C. Ricklefs sentence, in Indonesia the symbols and concepts of Islam are so attractive in political contestation. ${ }^{9}$

\section{Framing Ahok's Leadership: Differentiating "Us" and "Them"}

Ahok's leadership as Governor of Jakarta, serving from Joko Widodo's resignation in 2014 until 2017, was framed through the raising of political identity ahead of local elections in Jakarta. Identity politics, reinforced through ethnic and religious issues, should not be relevant in any elections, including those in Jakarta. However, the use of identity politics indicates the region's local democracy. If we further examine the meaning of pilkada, we can look at Article 18, paragraph 4, of the 1945 Constitution, which stipulates, "Governors, Regents, and Mayors are elected democratically". The phrase 'democratically elected', particularly its term 'democratic', can be interpreted with various definitions. In the context of local elections in Indonesia, the word 'democratically elected' means that the community must be actively involved in local elections so that every voter can use the political right to determine their leader.

The basis of democracy is the rationality that measures candidates' capacity on the basis of their ability and how the electorate has the ability to choose leaders who are able to build Jakarta and bring prosperity to its residents through solutive programs rather than a basis of religious and tribal similarities. That identity politics were an issue in the 2017 election indicates that it did not result in political transformation. Democratization follows the concept of liberal democracy, which emphasizes only free and open elections. Unfortunately, from year to year the power of political transformation was reduced and gave rise to political exclusion. This tendency was found not only in Jakarta, but also in other areas. This condition, of course, will lead to vulnerability in local democracy that impacts public distrust of democratic institutions. ${ }^{10}$

Local elections should be a very important form of political expression, because the people have the right to elect regional leaders and expect them to serve the community, promote regional development, and serve the interests of the nation and state. In this context, Jakarta, which is the capital of Indonesia and home to the central government, is often used as a barometer of politics in the region, failed to realize that expectation. The Jakarta elections is inappropriate as an example for other regional elections, because the use of identity politics indicates that the election was not yet sufficiently mature as a local

${ }^{8}$ Bayu Mitra A. Kusuma and Theresia Octastefani. "Negosiasi Dakwah dan Politik Praktis: Membaca Orientasi Organisasi Sayap Keagamaan Islam pada Partai Nasionalis". Al-Balagh: Jurnal Dakwah dan Komunkasi Vol. 2 No. 1 (2017), 3.

${ }^{9}$ Merle Calvin Ricklefs. Islamisation and Its Opponents in Java: A Political, Social, Cultural and Religious History c. 1930 to the Present. (Singapore: National University of Singapore Press, 2012). 275.

10 See Muhtar Haboddin. "Menguatnya Politik Identitas di Ranah Lokal". Jurnal Studi Pemerintahan Vol. 3 No. 1, (2012). 
Al Izzah: Jurnal Hasil-Hasil Penelitian-ISSN: 1978-9726 (p); 2541-0717 (e)

Volume 14, Nomor 2 (November, 2019))

democratic process. This is quite unfortunate, especially since Jakarta has a separate law that has become lex specialis in gubernatorial elections: to be elected governor, a candidate must receive more than $50 \%$ of votes. This has been reinforced by Regulation of the General Elections Commission Number 6 of 2016. As such, the implementation of electoral democracy through educative ways in Jakarta is very important, as it can become a source of knowledge about local politics for other regions throughout Indonesia. Critical and transformative political reasoning must serve as the basis for choosing leaders and creating a substantive democracy in which residents act as active citizens.

Ideally, the local election in Jakarta as capital city should provide the space and options for the community to select candidate leaders with strong capacity and commitment as well as social legitimacy, to ensure that any leader can enjoy the support and confidence of constituents, produce better decisions, and encourage a sense of mutual responsibility. In such a situation, the people will be more supportive of their elected leader's policies because the electorate has played a direct role in the leader's appointment. Unfortunately, the framing of Ahok through identity politics was used and controlled by political elites to strengthen the position of other gubernatorial candidates, particularly before the first round of elections was held on February 15, 2017.

Table 2; Analysis of Political Strength in the First-Round

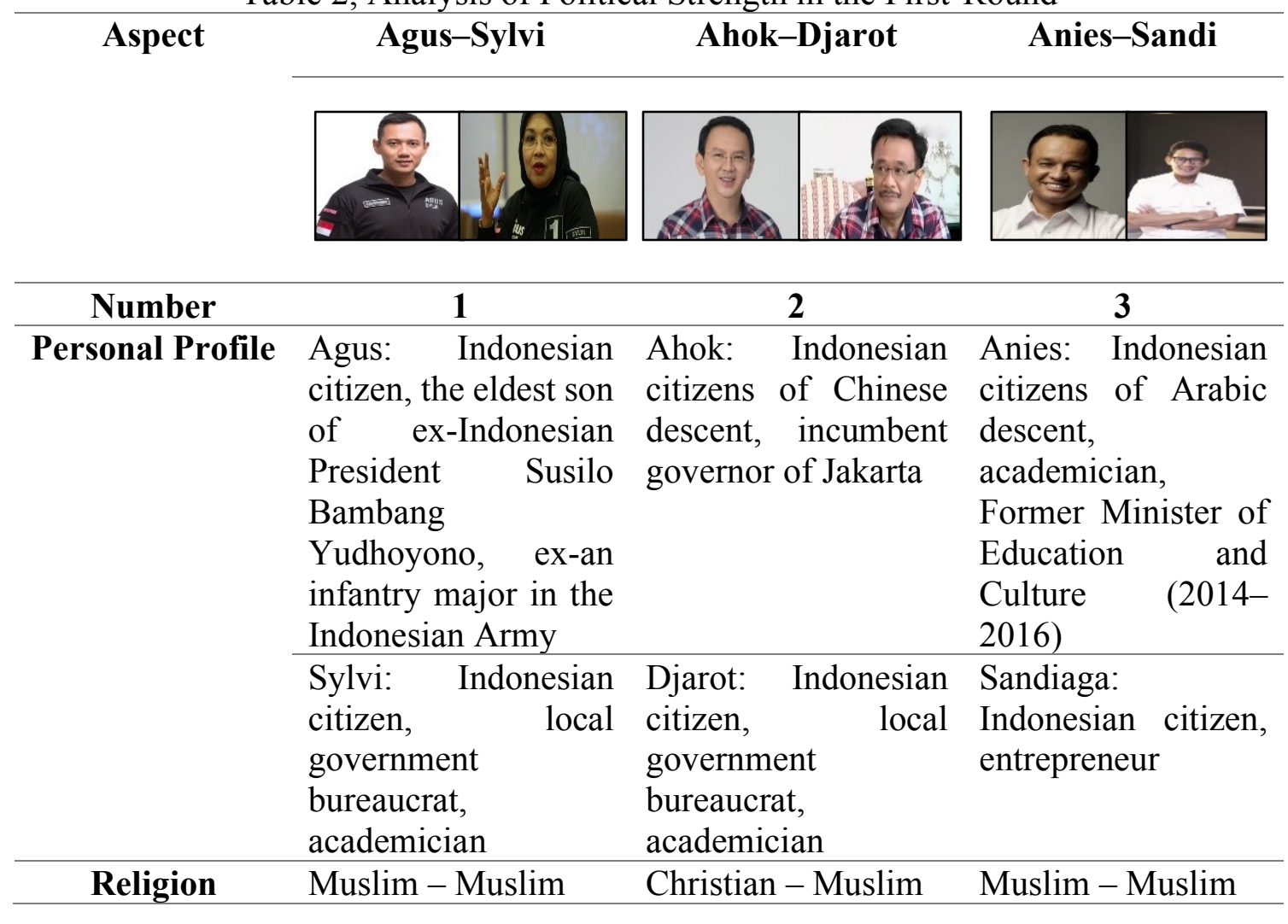


Al Izzah: Jurnal Hasil-Hasil Penelitian-ISSN: 1978-9726 (p); 2541-0717 (e)

Volume 14, Nomor 2 (November, 2019))

\begin{tabular}{|c|c|c|c|}
\hline Political Party & $\begin{array}{l}\text { 1. Democratic } \\
\text { Party/PD }(10 \\
\text { seats) } \\
\text { 2. National } \\
\text { Awakening Party } \\
\text { /PKB (6 seats) } \\
\text { 3. United } \\
\text { Development } \\
\text { Party /PPP (10 } \\
\text { seats) } \\
\text { 4. National Mandate } \\
\text { Party/PAN } \\
\text { seats) }\end{array}$ & $\begin{array}{l}\text { 1. Indonesian } \\
\text { Democratic Party } \\
\text { of Struggle/PDI-P } \\
\text { (28 seats) } \\
\text { 2. National } \\
\text { Democratic Party/ } \\
\text { Nasdem (5 seats) } \\
\text { 3. Functional Groups } \\
\text { Party / Golkar (9 } \\
\text { seats) } \\
\text { 4. People's } \\
\text { Conscience Party/ } \\
\text { Hanura (10 seats) }\end{array}$ & $\begin{array}{l}\text { 1. Greater Indonesia } \\
\text { Movement Party/ } \\
\text { Gerindra } \\
\text { seats) } \\
\text { 2.Prosperous } \\
\text { Justice Party/PKS } \\
\text { (11 seats) }\end{array}$ \\
\hline $\begin{array}{l}\text { Number of } \\
\text { seats in the } \\
\text { Jakarta } \\
\text { Parliament }\end{array}$ & 28 seats $(26.4 \%)$ & 52 seats $(49.1 \%)$ & 26 seats $(24.5 \%)$ \\
\hline
\end{tabular}

Source: Processed from various related data, 2018.

Based on the above table, running mates' number 2 (Ahok-Djarot) were superior in terms of political support, as they were carried by four nationalist political parties that had the largest number of seats in the Jakarta Regional Parliament. As such, the political base of Ahok-Djarot was much stronger than that of the other candidates. Hope of an Ahok victory still existed, despite the opposition's focus on Ahok's identity as a dual minority and the blasphemy charges that emerged in the middle of the campaign. In the first round of voting results, Ahok-Djarot outperformed the other candidates. They received 2,357,785 votes $(42.96 \%)$. In second place were Anies-Sandi, who received 2,193,530 votes (39.97\%). Agus-Sylvi obtained the least votes, only 936,461 (17.06\%). The results of the first-round election can be seen in the following picture.

Picture 1; Vote Count in the First-Round Election

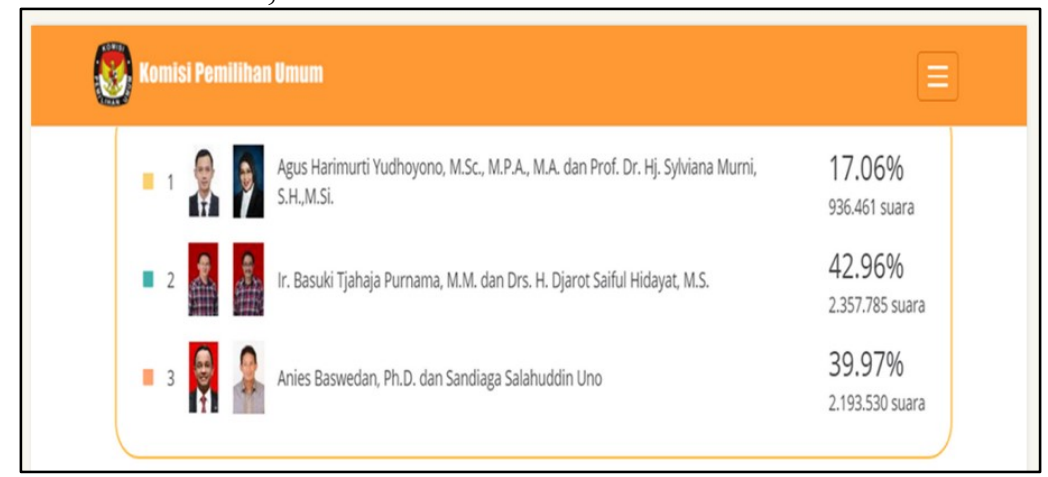


Al Izzah: Jurnal Hasil-Hasil Penelitian-ISSN: 1978-9726 (p); 2541-0717 (e)

Volume 14, Nomor 2 (November, 2019))

\section{Source: Official Website of KPU of East Jakarta City. ${ }^{11}$}

Unfortunately, none of the candidates managed to obtain the $50 \%+1$ vote required to immediately claim the election. As such, the Jakarta Elections Commission was required to hold a second round of elections in which Ahok-Djarot and Anies-Sandi competed to win the hearts of the people of Jakarta. Various efforts were made by both candidates during the second round of the campaign. On April 19, 2017, the second-round election was held. The results of the vote count are below.

Picture 2; Vote Count in the Second-Round Election

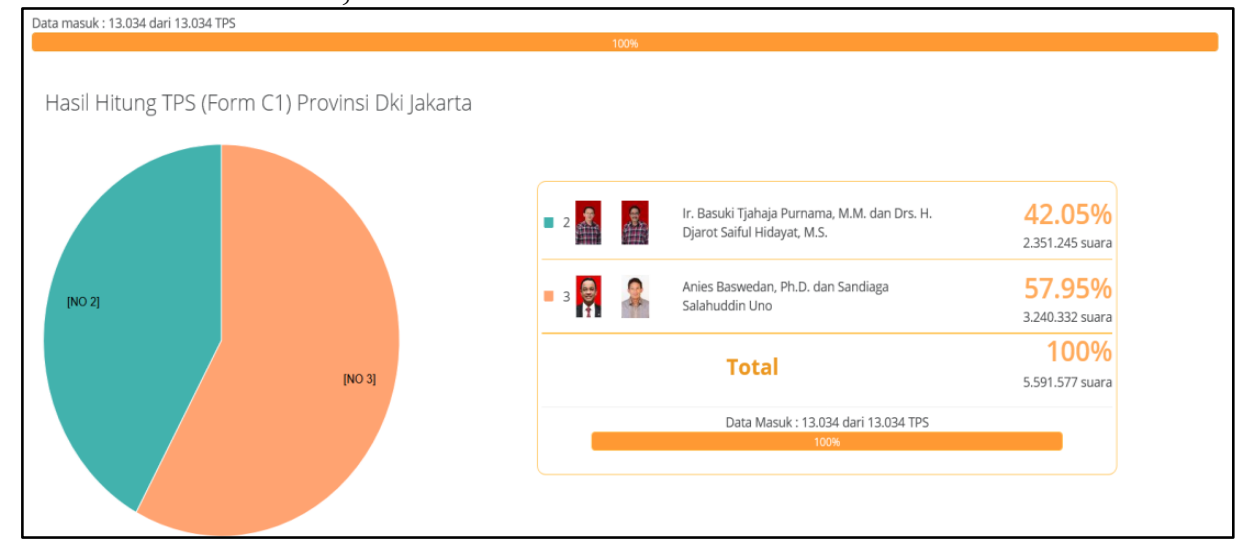

Source: Official website of KPU of the Republic of Indonesia. ${ }^{12}$

The second-round result of the Jakarta election concluded with a victory for Anies-Sandi, who will respectively begin their terms as governor and vice-governor in October 2017. Anies-Sandi received the most votes, 3,240,332 votes (57.95\%), while Ahok-Djarot were only able to obtain $2,351,245$ votes $(42.05 \%)$. Comparing the results of the first and second rounds of the election, it can be seen that Anies-Sandi gained votes from persons who had previously supported Agus-Silvi, while Ahok-Dajarot received 6540 votes $(0.27 \%)$ fewer votes than in the first round. A detailed comparison of the vote count is as follows.

11 General Elections Commission of East Jakarta City. 2017. Retrieved from http://kpujakartatimurkota.go.id/hasil-pilgub-dki-diperkirakan-dua-putaran/

12 General Elections Commission of the Republic of Indonesia, "Pilkada Provinsi DKI Jakarta (Putaran Kedua)", 2017, Retrieved from: https://pilkada2017.kpu.go.id/hasil/2/t1/dki_jakarta 
Al Izzah: Jurnal Hasil-Hasil Penelitian-ISSN: 1978-9726 (p); 2541-0717 (e)

Volume 14, Nomor 2 (November, 2019))

Table 3; Comparative Analysis of the Results of First and Second Round Election

\begin{tabular}{lcccc}
\hline \multirow{2}{*}{ Candidates } & \multicolumn{2}{c}{$\mathbf{1}^{\text {st }}$ round } & \multicolumn{2}{c}{$\mathbf{2}^{\text {nd }}$ round } \\
\cline { 2 - 5 } & Votes & $\mathbf{\%}$ & Votes & \% \\
\hline Agus-Sylvi & 936,461 & 17.06 & & 42.05 \\
\hline $\begin{array}{l}\text { Ahok- } \\
\text { Djarot }\end{array}$ & $2,357,785$ & 42.96 & $2,351,245$ & 57.95 \\
\hline $\begin{array}{l}\text { Anies- } \\
\text { Sandi }\end{array}$ & $2,193,530$ & 39.97 & $3,240,332$ & \\
Source: & & & &
\end{tabular}

Source: Processed by author from the official website of KPU of the Republic of Indonesia and East Jakarta City, 2017.

The defeat of Ahok-Djarot in the second round was predicted by a number of political circles, as well as survey agencies and public consultants. ${ }^{13}$ The cause of this pair's defeat can be attributed to a number of reasons. First, most of losing voters of AgusSilvi in first round choose to give their vote to Anies-Sandi in the second round. Second, the policy promoted by Ahok-Djarot was not considered pro-people. In a number of debates conducted before the first and second round of elections, some people of Jakarta gained the impression that Ahok-Djarot were not pro-people, as especially shown in policies related to settlement and reclamation in North Jakarta.

Third, religious and primordial issues were capitalized. Some people who were against the policy of Ahok compounded this with various SARA issues. Ahok was deemed to no longer be worthy of leading Jakarta in the next period, especially since he was facing legal issues for allegedly defaming religion. As he was ensnared in a legal case, this further strengthened sentiment towards Ahok, and some Jakarta voters no longer wanted to be led by people who embraced a different religion than that embraced by the majority of Jakarta's population. Fourth, Ahok's communication style seemed arrogant and rude. In his nearly three years leading Jakarta, Ahok was considered arrogant and rude when communicating. This type of communication was considered inappropriate for future leadership of Jakarta.

Fifth, inconsistent progress was made on individual tracts. Formerly, Ahok intended to progress through independent channels and not use political parties. Ahok was then greeted enthusiastically by a number of democracy activists, especially younger ones who were tired of political transactions between candidates and political party leaders. This led to the emergence of various volunteer groups for Ahok, including Friends of Ahok, DAG DKI, etc. Unfortunately, ahead of the registration period, Ahok did not receive sufficient support (in the form of residents' identity cards), and as a result he ran through political parties. Sixth, was the emergence of two other new candidates. The

13 See Tempo. Enam Lembaga Rilis Hasil Survei Pilkada DKI, Ahok Unggul. Retrieved from https://pilkada.tempo.co/read/840828/enam-lembaga-rilis-hasil-survei-pilkada-dki-ahok-unggul. 
presence of Agus-Silvi and Anies-Sandi in the election gave voters an alternative in determining who would lead Jakarta.

The defeat of the incumbent pair on April 19, 2017 did not necessarily draw the masses to discuss the pros and cons of each candidate. The legal case against Ahok continued until finally, on May 9, 2017, the Panel of Judges read the verdict against him: Ahok was found guilty of blasphemy and sentenced to two years imprisonment, despite having only been sentenced to one year in prison and a two-year probation in a previous case. Ahok fell afoul of Article 156a of the Criminal Code, handling religious defamation, and received a punishment stricter than that demanded by the prosecution's demands that he be charged under Article 156 on the expression of hostility and hatred towards a group. This punishment has become the biggest test for religious tolerance faced in the heterogeneous Indonesia. A sense of "unity" has been lost in the process of democratization and decentralization. This is as confirmed by Santoso,${ }^{14}$ who states that "when discussing democracy, what we highlight are only the actions of public officials, as if we do not do the same. We demand a change of system, but there is no seriousness to contribute to the realization and consolidation of the system we want." This statement is very interesting and appropriate to describe the condition in Jakarta today.

With the passing of the verdict, Ahok could not complete his leadership until the end of his period as governor of Jakarta. Ahok was deactivated from his position following the stipulations in Article 83, Paragraphs 1, 2, and 3, of Law No. 23 of 2014 regarding the dismissal of regional leaders. First paragraph reads "The regional head and/or deputy regional head shall be temporarily suspended without going through the proposal of the Regional Parliament if charged with committing a criminal offense punishable by a maximum imprisonment of 5 (five) years, corruption, terrorism, criminal offenses against state security, and/or other acts which may divide the Unitary State of the Republic of Indonesia".

Meanwhile, second paragraph reads "A regional head and/or deputy head who becomes a defendant as referred to in Paragraph (1) shall be suspended by court register in court". Moreover, third paragraph states, "The temporary dismissal of the regional head and/or deputy regional head referred to in Paragraph (1) and Paragraph (2) shall be enacted by the President for governors and/or vice governors and by the Minister for regents and/or deputy regents or mayors and/or deputy mayors". Under these articles, Ahok's position as Governor of Jakarta was suspended. To avoid vacancy of office and enable the continued practice of gubernatorial duties, Djarot Saiful Hidayat replaced Ahok as Acting Governor.

14 Purwo Santoso. "Menolak Stagnasi Demokratisasi: Otonomi Daerah sebagai Aktualisasi". Riptek Vol. 5 No. 1 (2011), 5-60. 
Al Izzah: Jurnal Hasil-Hasil Penelitian-ISSN: 1978-9726 (p); 2541-0717 (e)

Volume 14, Nomor 2 (November, 2019))

\section{What's Next: In-Depth Concern for the Prospect of Local Democracy in Jakarta?}

The implementation of local democratization through local elections is expected to answer the need for improving the quality of democracy. The practice of strong party oligarchy in the local elections system through legislative members is irrelevant, especially in this time of reform. This means that local elections are necessary to test the public's ability to elect democratic regional heads and truly realize democratization. The higher the quality of community participation will make the better the quality of the community in determining who will lead the area. If we look at the post-election situation in Jakarta, the question arises the future prospects for local democracy in Jakarta. Were the groups opposed to Ahok finally able to control their anger after Ahok was sentenced to jail and lost in the second round of elections? Was the group that supported Ahok ultimately able to accept the victory of Anies-Sandi and the court's verdict? After the second round of elections, will the residents of Jakarta be able to co-exist again? All of these questions will be analyzed further using the political representation approach.

The author realizes that there has been a change in the concept of representation along with the dynamics of political change. Referring to the concept of representation presented by Hanna Fenichel Pitkin in her book entitled The Concept of Representation explains that representation is divided into four categories, namely: first, formalistic representation, understood as political representation that takes place within formal representative institutions. Second, substantive representation is a model of representation in which a representative acts for those who are represented. Third, descriptive representation is understood as a form of representation where a representative stands for objectively similar people. Fourth, symbolic representation refers to those who are represented but in terms of the similarity of identity and culture. ${ }^{15}$ Based on the categorization of Pitkin's representation, Törnquist offers a new approach to understanding representation.

Törnquist and Warouw explains in contemporary political representation is related to four main elements, namely: in a political context, representation requires representatives, the represented, and something being represented. First, representatives are a group of people who represent well in formal representative institutions. Second, what is represented refers to the presence of a group of people represented where they can be constituents or clients. Third, something that is represented refers to the existence of interests, opinions, or political preferences. Fourth, the political context underlying this representation. ${ }^{16}$

\footnotetext{
${ }^{15}$ Hanna F. Pitkin, The Concept of Representation. (California: University Of California Press, 1967).

${ }^{16}$ Olle Törnquist and Nicolaas Warouw. "Memahami Demokrasi: Beberapa Catatan Pendahuluan tentang Konsep dan Metode”. in Willy Purna Samadhi and Nicolaas Warouw (eds.). Building Democracy on the Sand: Advances and Setbacks in Indonesia. (Yogyakarta and Jakarta: PCD Press and Demos, 2009). $19-44$.
} 
Al Izzah: Jurnal Hasil-Hasil Penelitian-ISSN: 1978-9726 (p); 2541-0717 (e)

Volume 14, Nomor 2 (November, 2019))

Furthermore, Törnquist, Webster, and Stokke divides representative forms into three categories. The first of these is symbolic representation, which refers to the extent to which representatives act to represent the represented and also the 'stands for' (i.e. cultural similarity and identity). Second is descriptive representation, which refers to the extent to which representatives can represent the 'stands for' of the persons they represent. Third is substantive representation, which is realized when those representing 'act for' their represented interests. Based on this discussion, my analysis indicates that the political situation in the Jakarta elections are directed more towards symbolic representation. This symbolic representation only emphasizes the necessity of a representative, without questioning the substance. This is evident from the electoral process, both before the first and second round of elections, where the citizens of Jakarta as voters were kept busy with issues of religion and ethnicity rather than candidates' visions, missions, and programs. See picture 3 below.

Picture 3; An Inclusive Model for the Study of Democracy oriented Representation

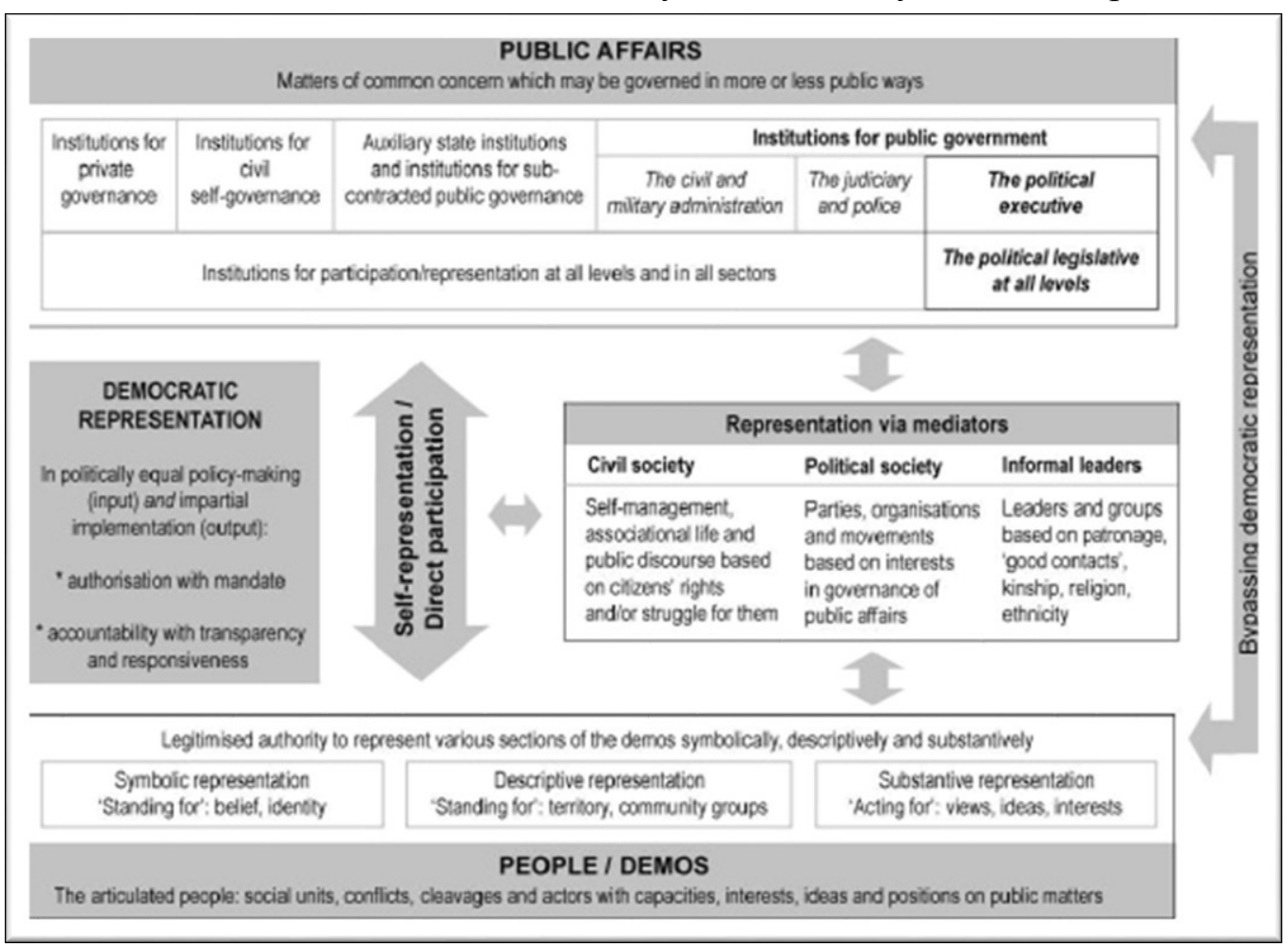

Source: Olle Törnquist, 2009. ${ }^{17}$

${ }^{17}$ Olle Törnquist. "Power, Conflict and Democracy: The Analytical Framework". PCD Journal: Power, Conflict, and Democracy Vol. 1 No. $1 \& 2$ (2009), 22. 
The picture above is a representation study framework offered by Törnquist to map and analyze studies not only seen from the workings of formal political representation, but also to offer a new approach to understanding the existence of informal political representation paths. This information is indicated by the presence of representative channels involving groups of community organizations (NGOs), civic groups, certain political elites, etc. which are represented based on similarities in identity (ethnicity, religion, interests, etc.) which have an influence on formal political representation.

The election of Anies-Sandi as Governor and Vice Governor of Jakarta for 20172022 illustrates that voters have a tendency to vote because of similarities in culture and identity. The widespread efforts to spread identity politics of various movements and actors, both from the top and bottom, worked to form 'the people' and establish the candidates' authority as legitimate representatives. The quality of political participation among Jakarta residents can also be seen from the extent of voter autonomy and literacy in determining positions. Were voters mobilized by political parties per se, or by primordial factors lacking rationality or conscience? If political alignments were established based on rational considerations, it is a positive sign for developing democracy and determining the format of the future. However, if the political choice of Jakarta citizens was motivated by the influence of identity politics, the future of democracy should be questioned. Symbolic representation will underlie the leadership of Anies-Sandi over the next five years.

\section{E. Local Democracy and Transformative Politics in the Transition Period}

The election in Jakarta 2017 should have been a moment for residents of Jakarta to conduct free elections unconditionally, without coercion from any party. However, during the process of democracy, some parties deliberately focused on issues that could lead to conflict. This can be seen in problems from previous elections. On May 10, 2016, the online newspaper Republika.co.id reported that, during the 2014 Presidential Election, then-presidential candidate Joko Widodo was branded as Chinese, communist, etc. by his opponents. ${ }^{18}$ Similar primordial issues were used as ammunition during the Jakarta election 2017. Social media was widely used to disseminate discussions that exploited issues of religion and ethnicity. This identity politics is deeply concerning.

These destabilizing identity politics may be successfully contained, and dominant political actors may be largely reconciled to the democratic "rules of the game". ${ }^{19}$ However, the emergence of identity themes such as Muslim, infidel, and Chinese in Indonesia's political sphere may actually tear at the woven unity that has been knitted.

18 Republika, "Isu SARA di Pilgub DKI 2017 Semakin Menggila", 2016, Retrieved from http://nasional.republika.co.id/berita/nasional/jabodetabek-nasional/16/05/10/o6ybdo282-isu-saradipilgub-dki-2017-semakin-menggila

${ }^{19}$ Olle Törnquist, "Stagnation or Transformation in Indonesia?", Economic and Political Weekly Vol. XLIX No. 50 (2014), 23-27. 
Even more concerning, some parties have capitalized on these identity politics. For instance, Ahok frequently repurposed identity issues to attack his opponents. He once made a statement, "Even though I am an infidel, I am not corrupt". This statement was not muffled, but instead increasingly contributed to the shape of politics before the Jakarta gubernatorial election.

The development of local democracy in Indonesia, in general, has focused more on figures who occupy the position of regional leader. There is a tendency for political parties and mass organizations to become less important in the electoral process, even as some use political parties and mass organizations to mobilize voters during elections. Efforts to Islamicize the plural Jakarta community through ethnic, racial, and religious emotional ties are meant predominantly to enhance political power. Can simultaneous elections realize transformative democratic politics? Political transformation is very important in the realization of substantive democracy in which a transformative leader is able to make significant changes. The deepening of democracy is not merely procedural. As such, attempts to activate citizens' political rights and create active citizens are most important in building local democracy in Jakarta. Sincerity in appreciating democratization and decentralization as a matter of political transformation is thus necessary. ${ }^{20}$ A nation's identity is not formed by itself, but through a lengthy process and struggle. Processing locality into nationality means processing of ethnic identity, religion, and plural fused groups into a nation that is "Bhinneka Tunggal Ika", "Many but One". This diversity must be compared, not contested. It is a manifestation of ideas and values that are mutually reinforcing and increase insight in mutual appreciation.

As the result of this analysis, there are several critical reflections regarding the Jakarta gubernatorial election, as follows. First, Muslim critics and power relations. The relationship between religion and politics is very dynamic, unique, and interesting. Sometimes the two exist side by side, while other times they contradict each other. Religion can perform its critical function as a medium of social criticism within society, as well as a means of political change. Officially, ethnicity, religion, race, and class had been political no-go areas in Indonesia, implying that public discourse about these topics was under close surveillance. ${ }^{21}$ The relationship between religion and politics is determined by which authority is the most powerful and dominant, as well as the character of religious and political elites. In this context, criticism appears very strong and is mobilized by hardliners who are intolerant, anti-pluralist, and counter-nationalist. They use primordial religious and ethnic considerations to achieve their political-economic interests. The mass mobilization involved in Islamic Defense Actions I-VII is a small but

\footnotetext{
${ }^{20}$ Purwo Santoso, “Menolak Stagnasi Demokratisasi: Otonomi Daerah sebagai Aktualisasi”, Riptek Vol. 5 No. 1 (2011), 45-60

${ }^{21}$ Henk Schulte Nordholt, "Decentralisation in Indonesia: Less State, More Democracy?”, in John Harriss, Kristian Stokke, and Olle Törnquist (eds), Politicising Democracy: The New Local Politics of Democratisation, (New York: Palgrave Macmillan, 2005), 45.
} 
striking example of religious politics. If this relationship is not well managed, the spirit of democracy that has faced extensive difficulties will be buried in the future.

Second, gap in modern growth: social and economic capital. Social and economic vulnerability in Jakarta are a logical consequence of the city's position as a political, social, economic, etc. center. As the capital of Indonesia, Jakarta is the foundation for the lives of millions of people living in the midst of economic growth. Vigorous development, in the form of rows of skyscrapers on various protocol roads and in business centers, can be seen by the naked eye. However, this development progress has not given birth to economic equity. Harriss, Stokke, and Törnquist write that: ${ }^{22}$

"The apparent weaknesses, however, of both the modernisation and the structural approaches for the explanation of the third wave of democratisation have certainly contributed to the ascendancy in the contemporary literature of the 'transition' approach, exemplified in the work of O'Donnell and Schmitter (1986), Linz and Stepan (1996) and others, which focuses on the agency of political elites."

This further reinforces the gap in the various cases of social and economic disparities between the rich and poor residents of Jakarta. This issue was central in the election campaign. Each candidate has a program to solve this problem. This issue received serious attention, as well as criticism that should be accommodated by each candidate.

Third, money politics: transactionalism. Money politics has always been present in every regional election. The practice of money politics varies from the distribution of donations (in the form of goods or money) to the abuse of authority and state facilities for the benefit of a candidate or political party bearer. As stated by the Indonesian Corruption Watch (ICW) on its official website, the organization has received numerous reports of alleged political transactions and money politics. ${ }^{23}$ Furthermore, the Electoral Supervisory Body for Jakarta received information about alleged practices of money politics, taking the form basic foods being distributed by supporters of each candidate before the second round of voting. With these basic foods, supporters distributed flyers inviting voters to select specific candidates. This alleged practice of money politics has become a critical note in the implementation of the elections in Jakarta.

Fourth, mass mobilization. In terms of mass mobilization, opinion wars - often filled with religious and ethnic issues - were very easily disseminated through various print, electronic, and social media. This can be seen in various posts in print, online, and social, including Twitter and Facebook. Some time ago, one group held a convention to

22 John Harriss, Kristian Stokke, and Olle Törnquist, "Introduction: The New Local Politics of Demoratisation”, in John Harriss, Kristian Stokke, and Olle Törnquist (eds.), Politicising Democracy: The New Local Politics of Democratisation, (New York: Palgrave Macmillan, 2005), 5.

${ }^{23}$ Indonesian Corruption Watch, "Pilkada DKI Jakarta di Bawah Ancaman Politik Uang dan Intimidasi", 2017, Retrieved from http://www.antikorupsi.org/id/content/pilkada-dki-di-bawah-ancamanpolitik-uang-dan-intimidasi 
search for a Muslim candidate to challenge Ahok in the election. The use of religious and ethnic issues to attack other groups before the election in Jakarta 2017 was certainly not healthy for the development of democracy in Jakarta and in Indonesia and may even threaten social relations and social security. The media should play an important role in political communication. Its interactive nature allows the political communication process to be done more intensely during the course of democratic life. Print, electronic, and social media should be utilized as an effective means of political communication to interact with the public and convey each candidate's political aspirations as well as to influence voters. With its political messages uploaded, each potential candidate can influence the general public through positive or negative support or through criticism. In the context of the Jakarta Election, uploads of videos depicting Ahok were a real and effective strategy used to attack him by claiming blasphemy. In a democracy, public opinion can be massively mobilized through the mass media.

Last, personality politics. Local elections are important tools for regenerating national leadership. Whether realized or not, the stock of national leadership is a very limited percentage of Indonesia's total population of more than 250 million people. These are mostly leaders of major political parties that won the 2004 elections. As such, hope for the rise of national leaders precisely from simultaneous local elections. Unfortunately, the condition differs from expectations. The new reality of Indonesia's local democracy is aimed precisely at the politics of cadres. Ahok was not respected by his political opponents for taking anti-corruption measures or for becoming a progressive actor at the provincial level. From these critical records, we must transform democracy into more than a form or state identity. It must become a praxis (Santoso, 2011, p.45). Transformation must be realized in the local democratization process in Indonesia, so that it becomes more than mere discourse.

\section{F. Concluding Remarks}

The Jakarta Gubernatorial Election 2017 can be used as a means of understanding local democracy in regions that will hold their local elections in the future, at least until 2027. The management of regional identity must show the diverse characteristics of the nation. As a unitary state, Indonesia is formed from various cultures and ethnicities, based on Pancasila, and the value of Bhinneka Tunggal Ika. Therefore, Jakarta, as a home for people of various religions and ethnic groups, should have the ability to manage multiple identities and safeguard coexistence as a manifestation of tolerance towards difference and diversity. Unity in diversity must serve as a directive, guideline, and reference for every person involved in building and maintaining national life, because Indonesian society is a multicultural one.

Cases of blasphemy should not occur if different believers are able to respect and value each other. In addition, if successful candidates for regional leader understand the true value of the diversity embodied in the slogan Bhinneka Tunggal Ika, they should not use identity issues to win elections, because such issues benefit only their own group's 
interests and not those of the nation and state. Therefore, it is important to create regional elections with zero conflict, as well as post-election periods in which efforts are made to restore harmony. Identity politics in Jakarta elections was used as a popular movement by some religious and political elites, not to promote the welfare of Jakarta's residents. Welfare issues appear to have worked because citizens became preoccupied with debates over religion and ethnicity. The elections in Jakarta 2017 offered momentum for the nation to learn from practices of local democracy that are expected to form a collective awareness about the importance of choosing leadership according to one's conscience. Transformative democratic politics cannot be realized if voters lack the ability to determine the pace of governance (ability to govern) in the future.

The Jakarta Gubernatorial Election shows the reality of the strengthening of symbolic representation compared to substantive representation. For this reason, in deepening democracy, the transformation from symbolic representation to substantive representation is a crucial part of collaborating in improving the quality of local democracy.

\section{Acknowledgments}

This paper was written as final report of short course on "Democracy and Social Democratic Development in the Global South", hosted by the Department of Political Science, University of Oslo, Norway, May 2-6, 2017. This research was funded by the Royal Norwegian Embassy in Jakarta as part of the "Power, Welfare, and Democracy" research project, conducted jointly by Universitas Gadjah Mada and the University of Oslo.

\section{REFERENCES}

Akbar, Idil. "Pilkada Serentak dan Geliat Dinamika Politik dan Pemerintahan Lokal Indonesia". CosmoGov: Jurnal Ilmu Pemerintahan Vol. 2 No. 1, 2016.

Aspinall, Edward \& Mada Sukmajati (eds.). Politik Uang di Indonesia: Patronase dan Klientelisme di Pemilu Legislatif 2014. Yogyakarta: PolGov UGM, 2015.

CNN Indonesia. Kronologi Kasus Buni Yani, Penyebar Video Ahok Soal Al Maidah. Retrieved from https://www.cnnindonesia.com/nasional/20161124075029-12174911/kronologi-kasus-buni-yani-penyebar-video-ahok-soal-al-maidah.

General Elections Commission of East Jakarta City. 2017. Retrieved from http://kpujakartatimurkota.go.id/hasil-pilgub-dki-diperkirakan-dua-putaran/

General Elections Commission of the Republic of Indonesia. Pilkada Provinsi DKI Jakarta (Putaran Kedua). 2017. Retrieved from: https://pilkada2017.kpu.go.id/hasil/2/t1/dki_jakarta

Haboddin, Muhtar. "Menguatnya Politik Identitas di Ranah Lokal". Jurnal Studi Pemerintahan Vol. 3 No. 1, 2012. 
Al Izzah: Jurnal Hasil-Hasil Penelitian-ISSN: 1978-9726 (p); 2541-0717 (e) Volume 14, Nomor 2 (November, 2019))

Hardiman, Budi F. "Demokrasi Deliberatif: Model untuk Indonesia Pasca-Soeharto?", Majalah Basis No. 11-12, 2004.

Harriss, John, Kristian Stokke, \& Olle Törnquist. "Introduction: The New Local Politics of Demoratisation". in John Harriss, Kristian Stokke, and Olle Törnquist (eds.). Politicising Democracy: The New Local Politics of Democratisation. New York: Palgrave Macmillan, 2005.

Indonesian Corruption Watch. "Pilkada DKI Jakarta di Bawah Ancaman Politik Uang dan Intimidasi". $2017 . \quad$ Retrieved from http://www.antikorupsi.org/id/content/pilkada-dki-di-bawah-ancaman-politikuang-dan-intimidasi

Kusuma, Bayu Mitra A. \& Theresia Octastefani. "Negosiasi Dakwah dan Politik Praktis: Membaca Orientasi Organisasi Sayap Keagamaan Islam pada Partai Nasionalis". Al-Balagh: Jurnal Dakwah dan Komunkasi Vol. 2 No. 1, 2017.

Nordholt, Henk Schulte. "Decentralisation in Indonesia: Less State, More Democracy?" In John Harriss, Kristian Stokke, \& Olle Törnquist (eds). Politicising Democracy: The New Local Politics of Democratisation. New York: Palgrave Macmillan, 2005.

Pitkin, Hanna F. The Concept of Representation. Berkeley: University of California Press, 1967.

Republika. "Isu SARA di Pilgub DKI 2017 Semakin Menggila". 2016. Retrieved from http://nasional.republika.co.id/berita/nasional/jabodetabeknasional/16/05/10/o6ybdo282-isu-sara-dipilgub-dki-2017-semakin-menggila

Ricklefs, Merle Calvin. Islamisation and Its Opponents in Java: A Political, Social, Cultural and Religious History c. 1930 to the Present. Singapore: National University of Singapore Press, 2012.

Sabandar, Switzy. Riset UGM: Ahok dan Pilkada DKI Isu Paling Populer Sepanjang 2016. Retrieved from https://www.liputan6.com/news/read/2836414/riset-ugmahok-dan-pilkada-dki-isu-paling-populer-sepanjang-2016.

Sahalatua, Andy Prima, et al. "Politik Identitas dalam Pemilihan Kepala Daerah (Studi Kasus pada Pemilihan Gubernur DKI Jakarta Periode 2017-2022)". Prosiding Seminar Nasional Prodi Ilmu Pemerintahan, 2018.

Samadhi, Willy Purna \& Nicolaas Warouw (eds). "Demokrasi di Atas Pasir: Kemajuan dan Kemunduran Demokrasi di Indonesia”. Jakarta: DEMOS and PCD Press, 2009.

Santoso, Purwo. "Menolak Stagnasi Demokratisasi: Otonomi Daerah sebagai Aktualisasi". Riptek Vol. 5 No. 1, 2011.

Sari, Endang. "Kebangkitan Politik Identitas Islam Pada Arena Pemilihan Gubernur Jakarta”. Kritis: Jurnal Ilmu Sosial dan Ilmu Politik Vol. 2 No. 2, 2016.

Tempo. Enam Lembaga Rilis Hasil Survei Pilkada DKI, Ahok Unggul. Retrieved from https://pilkada.tempo.co/read/840828/enam-lembaga-rilis-hasil-survei-pilkadadki-ahok-unggul 
Al Izzah: Jurnal Hasil-Hasil Penelitian-ISSN: 1978-9726 (p); 2541-0717 (e)

Volume 14, Nomor 2 (November, 2019))

Törnquist, Olle. "Stagnation or Transformation in Indonesia?". Economic and Political Weekly Vol. XLIX No. 50, 2014.

Törnquist, Olle. "Power, Conflict and Democracy: The Analytical Framework". PCD Journal: Power, Conflict, and Democracy Vol. 1 No. $1 \& 2,2009$.

Törnquist, Olle \& Nicolaas Warouw. "Memahami Demokrasi: Beberapa Catatan Pendahuluan tentang Konsep dan Metode". in Willy Purna Samadhi and Nicolaas Warouw (eds.). Building Democracy on the Sand: Advances and Setbacks in Indonesia. Yogyakarta and Jakarta: PCD Press and Demos, 2009. 